\title{
Inflammation in human skin induced by ultraviolet irradiation
}

\author{
N. A. Plummer \\ Ph.D. \\ M. W. Greaves \\ Ph.D., M.D., F.R.C.P.
}

\author{
C. N. HeNSBY \\ B.Sc.
}

A. KobZA BLACK
M.R.C.P.

\section{Professorial Unit, Institute of Dermatology, St John's Hospital for Diseases of the Skin, London}

\begin{abstract}
Summary
Pharmacologically active mediators of inflammation were obtained from suction bullae raised on normal and ultraviolet B (290-320 $\mathrm{nm})$ inflamed human abdominal skin. The exudates obtained from the bullae were examined by superfusion cascade bioassay, by radioimmunoassay for $\mathbf{P G F}_{2 \alpha}$ and by column, thin-layer and gas-liquid chromatography.

Ultraviolet B (u.v.-B) irradiation of human skin produced an erythema which appeared after $2 \mathrm{hr}$, increased in severity up to $24 \mathrm{hr}$ and persisted for more than $48 \mathrm{hr}$. Bioassayable and radioimmunoassayable prostaglandin activity was elevated at $6 \mathrm{hr}$, was maximal at $24 \mathrm{hr}$ and had returned to normal by $48 \mathrm{hr}$. Topical application of indomethacin suppressed both the erythema and the increased concentration of $\mathbf{P G F}_{2 \alpha}$ as measured by radioimmunoassay. Chromatographic studies confirmed increased prostaglandin activity at 6 and $24 \mathrm{hr}$ and in addition demonstrated an increase in arachidonic acid-like activity.

The results suggest that prostaglandins may play an important role between 6 and $24 \mathrm{hr}$ of u.v.-Binduced erythema. Whether the reduction of erythema by indomethacin can be partially or wholly attributable to inhibition of prostaglandin biosynthesis is uncertain.
\end{abstract}

\section{Introduction}

The mechanisms by which ultraviolet radiation (u.v.r.) causes erythema is unknown. One possibility is that u.v.r. erythema is mediated by one or more vasoactive substances which act on the skin vasculature. This type of erythema may be suppressed by non-steroidal anti-inflammatory drugs, such as aspirin and indomethacin (Miller, Ruderman and Smith, 1967; Snyder and Eaglstein, 1974), which are known prostaglandin synthetase inhibitors. In addition, Sondergaard and Greaves (1970) have implicated prostaglandins as possible mediators in u.v.-B-induced erythema.

It was therefore of interest to study prostaglandinlike activity in human skin at various intervals following u.v.-B irradiation.

\section{Materials and methods}

Two areas of clinically normal abdominal skin of thirty-three adult volunteers was irradiated with three times the minimal erythema dose (3 MED) of u.v.-B (290-320 nm) using four FS 20 Westinghouse sun tubes, having an intensity of $430 \mu \mathrm{Wcm}^{-2}$ at $30 \mathrm{~cm}$. Immediately after irradiation $2.5 \%$ indomethacin was applied to one irradiated area at a dosage of $3 \mu \mathrm{cm}^{-2}$. The degree of erythema was assessed visually. Exudate was collected, at 6, 24 and $48 \mathrm{hr}$ after irradiation, from irradiated and control non-irradiated skin by a suction bullae technique (Black et al., 1976). The exudates were examined foro smooth muscle contracting activity by superfusion cascade bioassay (Vane, 1964) and for PGF $_{2 \alpha}$ by radioimmunoassay. Ethyl acetate extractable fractions from the exudates were examined for various prostaglandins and related compounds by Lipidex 5000 gel partition, thin-layer and gas-liquid chromatography as previously described by Plummer et al. (1977).

\section{Results}

Irradiation of human abdominal skin produced erythema in all subjects studied. The erythema appeared at $2 \mathrm{hr}$, was maximal at $24 \mathrm{hr}$ and persisted for more than $48 \mathrm{hr}$. Topical indomethacin partially suppressed the erythema seen at $24 \mathrm{hr}$. Prostaglandin-like activity was detected by bioassay in exudate from normal non-irradiated skin. At 6 and $24 \mathrm{hr}$ after irradiation the concentrations of prostaglandin-like activity were significantly increased. However, at $48 \mathrm{hr}$ the concentration was not significantly different from that of the control (Table 1). Similarly, radioimmunoassayable PGF $_{2 a}$ was significantly elevated at $24 \mathrm{hr}$. Initial studies indicate that the concentrations of immunoassayable $\mathrm{PGF}_{2 \alpha}$ seen $24 \mathrm{hr}$ after u.v.-B irradiation were prevented by topical application of indomethacin (Table 1).

Chromatographic studies suggest that u.v.-B 
TABLE 1. Concentrations of prostaglandin-like activity in exudate from human skin at 6,24 and 48 hr after u.v.-B irradiation and the effect of indomethacin on $\mathrm{PGF}_{2 \alpha}$ at $24 \mathrm{hr}$ after irradiation

\begin{tabular}{|c|c|c|c|c|c|c|}
\hline \multirow[t]{2}{*}{ Method } & \multirow[t]{2}{*}{ Compound } & \multirow[t]{2}{*}{ Control } & \multicolumn{4}{|c|}{$\begin{array}{l}\text { Time after irradiation } \\
(\mathrm{hr})\end{array}$} \\
\hline & & & 6 & 24 & $\begin{array}{c}24+ \\
\text { (Indomethacin) }\end{array}$ & 48 \\
\hline Bioassay & $\begin{array}{l}\text { PG-like* } \\
\text { ng/ml }\end{array}$ & $\begin{array}{l}31 \cdot 3 \pm 12 \cdot 6 \\
n=10\end{array}$ & $\begin{array}{l}100 \pm 17 \cdot 7 \\
\mathrm{n}=4 \\
P<0.02\end{array}$ & $\begin{array}{l}243 \cdot 8 \pm 90 \cdot 4 \\
\mathrm{n}=4 \\
P<0.005\end{array}$ & & $\begin{array}{l}56 \cdot 3 \pm 19 \cdot 4 \\
n=4 \\
P>0 \cdot 30\end{array}$ \\
\hline Radioimmunoassay & $\begin{array}{l}\mathrm{PGF}_{2 \alpha} \\
\mathrm{ng} / \mathrm{ml}\end{array}$ & $\begin{array}{l}21 \cdot 3 \pm 4 \cdot 8 \\
n=27\end{array}$ & $\begin{array}{l}43 \cdot 8 \pm 16 \cdot 5 \\
n=9 \\
P>0 \cdot 10\end{array}$ & $\begin{array}{l}56 \cdot 7 \pm 9 \cdot 0 \\
\mathrm{n}=11 \\
P<0 \cdot 0005\end{array}$ & $\begin{array}{l}11 \cdot 3 \pm 5 \cdot 6 \\
\mathrm{n}=9 \\
P>0.5\end{array}$ & $\begin{array}{l}22 \cdot 7 \pm 4 \cdot 7 \\
\mathrm{n}=8 \\
P>0 \cdot 40\end{array}$ \\
\hline
\end{tabular}

* Measured as $\mathrm{PGE}_{2}$ equivalents.

irradiation increases the concentration of arachidonic acid, $\mathrm{PGE}_{2}$ and $\mathrm{PGF}_{2 \alpha}$ at 6 and $24 \mathrm{hr}$ after irradiation. Likewise, these techniques failed to provide evidence of elevated prostaglandins at $48 \mathrm{hr}$ when the erythema was still present.

\section{Discussion}

The present study provides evidence of a rise in human skin prostaglandin and arachidonic acid-like activity at 6 and $24 \mathrm{hr}$ after u.v.-B irradiation when erythema is developing. However, at $48 \mathrm{hr}$, when the erythema is still maximal, the levels of prostaglandins and arachidonic acid-like activity were not significantly different from the controls. These findings raise the possibility that prostaglandins may be important mediators of inflammation at 6 and $24 \mathrm{hr}$ after U.v.-B irradiation, since the erythema and prostaglandins are suppressed by indomethacin. However, other mediator(s) may be important at $48 \mathrm{hr}$, or the erythema seen at $48 \mathrm{hr}$ could result not from increased blood flow but to a pooling of blood in the skin. Alternatively, the increased prostaglandin activity in u.v.-B-induced inflammation may be unrelated to the concomitant development of redness; the suppressive effect of indomethacin on u.v.-B erythema being attributable to actions of indomethacin other than its ability to suppress prostaglandin synthesis. Studies of the quantitative relationships between changes in concentrations of prostaglandins and related compounds, other non-prostaglandin mediators and blood flow in irradiated skin are needed.

\section{Acknowledgments}

This work was supported by grants from the Medical Research Council and Wellcome Trust. We thank Miss M. Davison for skilled technical assistance. Grateful thanks go to Professor E. W. Horton (Edinburgh) and Dr J. Pike (Upjohn Co.) for generous gifts of antiserum and prostaglandin respectively.

\section{References}

Black, A., Greaves, M.W., Hensby, C.N. \& Plummer, N.A. (1976) A new method of obtaining human skin inflammatory exudate for pharmacological analysis. British Journal of Pharmacology, 58, 317.

Miller, W.S., Ruderman, F.R. \& SMith, J.G. (1967) Aspirin and ultraviolet light-induced erythma in man. Archives of Dermatology, 95, 357.

Plummer, N.A., Hensby, C.N., Black, A. \& Greaves, M.W. (1977) Prostaglandin activity in sustained inflammation of human skin before and after aspirin. Clinical Science and Molecular Medicine, 52, 615.

SNYDER, D.S. \& EAGLSTEIN, W.H. (1974) Topical indomethacin and sunburn. British Journal of Dermatology, 90, 91.

SondergaARD, J. \& Greavfs, M.W. (1970) Pharmacological studies in inflammation due to ultraviolet radiation. Journal of Pathology, 101, 93.

VANE, J.R. (1964) The use of isolated organs for detecting active substances in the circulating blood. British Journal of Pharmacology, 23, 360. 